\title{
A PAIR rajzelemzési technika alkalmazása 8-9 éves gyermekek győzelemmel és vesztéssel kapcsolatos rajzain
}

\author{
Sándor Mónika ${ }^{1}$ \\ MTA Pszichológiai Kutatóintézet \\ sandormoni@mtapi.hu \\ Fülöp Márta \\ MTA Pszichológiai Kutatóintézet \\ fmarta@mtapi.hu \\ Sebestyén Nóra \\ MTA Pszichológiai Kutatóintézet \\ nora.sebestyen@mtapi.hu
}

\begin{abstract}
A versengés olyan társas magatartásforma, amely kimeneteleivel, a győzelemmel illetve vesztéssel karöltve végig kíséri életünket, jelen van kisgyermekkortól az időskorig. A napi iskolai élet számtalan strukturális és spontán versenyhelyzetet teremt, amelynek során a gyermekek alakíthatják versengéssel kapcsolatos attitüdjüket és a győzelemmel és vesztéssel kapcsolatos megküzdési stratégiáikat. A versengés tárgyai lehetnek az osztályzatok, a tanulmányi teljesítmény, a tanár figyelme, megbecsülése, elfogadása, a társak szeretete, a népszerüség vagy éppen a vezető szerep az osztályban (Fülöp, 2001). A versengés jelen van a családban, a játszótéren, az iskolán kívüli sportban és természetesen a médiában is. Iskoláskorban tehát a gyermekek már gazdag információval rendelkeznek ahhoz, hogy a győzelemmel és vesztéssel kapcsolatban árnyalt és kidolgozott mentális reprezentációt alakítsanak ki, amely segíti őket a fogalmak értelmezésében és kezelésében (Fülöp és Sándor, 2008). Jelen vizsgálat célja a győzelem és vesztés fogalmának, valamint a két szituációban megjelenített győztes és vesztes viszonyának feltárása volt kisiskolások képi reprezentációjában. A vizsgálat konkrét bemutatása előtt sorra vesszük a társas viszonyulások értelmezésében szerepet játszó kognitív bázis alakulását kisiskoláskorban, a győzelemre és vesztésre adott reakciók természetét, a versengésről való gondolkodásban szerepet játszó iskolai szocializációt, valamint az iskoláskorra megjelenő versengéssel kapcsolatos nemi különbségeket.
\end{abstract} A versengés értelmezésében, a társas viszonyok leképezésében szerepet játszó mentális
struktúra alakulása kisiskoláskorban

A versengés alapja a társas összehasonlítás; kialakulásához elengedhetetlenül szükség van arra, hogy a gyerek képes legyen önmagát és társát egyszerre fókuszban tartani és rendelkezzen a társ helyzetéről és szándékairól valamiféle megértéssel. A pszichológiai kutatások egyre gyakrabban foglalkoznak a metakogníció fejlődésével és azzal, hogy a gyerekeknek az alapvető elmeállapotokról, vágyakról, észlelésről, hiedelmekről, szándékokról és érzésekről milyen elképzeléseik vannak (Flavell, 1999). A mentalizáció az olyan társas jelenségekkel kapcsolatban, amilyen a versengés is, különösen nagy jelentőséggel bír, mivel ezen folyamatokban a másik reakciójának kiszámítása, vagy teljesítményének megjóslása alapjaiban befolyásolja az alkalmazott társas összehasonlítást vagy versengési stratégiát és az ezzel kapcsolatos értékelési folyamatot is.

\footnotetext{
${ }^{1}$ A tanulmány megírása során a szerzők az OTKA (K 77691) kutatási támogatásában részesültek. Projekt vezetö: Fülöp Márta
} 
Bartsch és Wellman (1995) a gyermeki elmeteória fejlődését három lépésben írja le. Ezek szerint a gyerekek kétéves koruk környékén kezdik megérteni, hogy az őket körülvevő embereknek is vannak gondolataik és elképzeléseik, ők is éreznek, örülnek, szomorúak vagy esetleg félnek valamitől. Mindezeket azonban még nem képesek leképezni, csak három éves kor körül kezdenek el róla beszélni és értik meg, hogy a vélekedéseik nem minden esetben helyesek és nem feltétlenül egyeznek másokéval. Végül négy éves koruk körül jutnak el oda, hogy megértsék, hogy mások vélekedései képesek befolyásolni viselkedésüket. Ezek a gyerekek egyre több időt töltenek közös játékkal és az egymás mellett létezést felváltják a társas interakciók, amelyek során a gyerek már képes figyelembe venni azt, hogy a másik mit gondol, és ennek következtében mit tesz egy adott helyzetben.

Ahhoz, hogy a gyermekek megértsék mások szándékait, elengedhetetlen a nézőpontváltás képessége. Selman (1980) a nézőpontátvétel képesség fejlődésének öt lépcsős hierarchikus modelljében felvázolja, hogy 3-6 éves gyermekek még összekeverik saját gondolataikat és érzésüket másokéval, 5-9 éves korukra képesek figyelembe venni, hogy léteznek eltérő nézőpontok, melyek hátterében információs különbségek állhatnak. A következő szinten, 7-12 éves koruk körül tudnak bele helyezkedni mások helyzetébe, és saját viselkedésüket azok szemszögéböl megítélni, 10-15 évesen már egy harmadik nézőpontot is figyelembe tudnak venni. Mások érzelmi állapotának feltérképezése szintén fejlődési folyamat eredménye. Míg a 3-4 éves korú gyermekek az érzelmek külső, viselkedésbeli megnyilvánulására támaszkodnak és az alapérzelmek kerülnek a fókuszba (pl. szomorúság-könnyek) (Pons, Lawson, Harris és de Rosnay, 2004), addig 5-8 éves korra képesek lesznek az érzelmek pszichológiai aspektusainak megértésére és olyan komplex vagy éntudatos érzelmek (pl. büszkeség, szégyen, féltékenység) felismerésére is, amelyek gyakran kísérő érzelmei a győzelemnek és vesztésnek (Saarni, 1999; Harter, 1999).

Kisiskolás korra a gyermekek tehát képessé válnak a versengés társas dinamikájának megértésére, a versenyhelyzet szereplői (győztes, vesztes) eltérő érzéseinek, gondolatainak feltérképezésére.

\section{A gyözelem és vesztés pszichológiája}

A győzelem és vesztés felfogható a siker és kudarc jól elkülöníthető alesetének, mely egy speciális kontextusban, strukturális vagy spontán versengés során a társas összehasonlítás eredményeképp létrejövő versengési eredmény (Fülöp és Berkics, 2007). Pekrun (1992) a teljesítménnyel kapcsolatos érzelmi élményeket kétféle dimenzió mentén csoportosította, melyek jól alkalmazhatóak a győzelemre és vesztésre adott reakciók tekintetében is. Az érzelmeket egyrészt kiváltó jellegük alapján pozitív és negatív kategóriába sorolta, másrészt a további tevékenységekre vonatkozóan aktiválónak vagy éppen deaktiválónak tekintette őket. A két dimenzió mentén négy kombináció jöhet létre: aktiváló pozitív érzelem (pl. öröm és büszkeség), deaktiváló pozitív érzelem (pl. megkönnyebbülés, relaxáltság), aktiváló negatív érzelem (pl. harag, frusztráció) és deaktiváló negatív érzelem (unalom, levertség, szomorúság, vagy ezek egy komplexebb változata, a depresszió).

A győzelem és vesztés olyan társas közegben zajló komplex jelenség, mely megértéséhez, a rájuk adott érzelmi reakciók feltérképezéséhez elengedhetetlen a szociális kontextus, a versengő felek, különös tekintettel a győztes és vesztes kapcsolatának mélyreható vizsgálata. Sloman és Gilbert (2000) evolúciós jelentőségünek és a humán pszichológián belül kiemelkedő fontosságúnak tekintik a vesztéssel való megküzdésre szolgáló stratégiákat és a vesztés elfogadását. Sloman (2000) szerint a vesztés elfogadásában a győztes és a vesztes 
közötti kapcsolat meghatározó szerepet játszik. Amennyiben a győztes folyamatosan megszégyeníti a vesztest, vagy szembesíti vesztésével, akkor ez haragot és ellenérzést kelt a vesztesben és megnehezíti a vesztés konstruktív feldolgozásának folyamatát. Bár a szakirodalom sokkal nagyobb figyelmet fordít a vesztés feldolgozására, a győzelem adaptív feldolgozása ugyanolyan szükséges (Brim, 1992). A társas közeg győzelemre és a győztesre adott reakciója, illetve e reakciótól való félelem nagyban befolyásolja a győzelem feldolgozásnak folyamatát. A szociális közeg reakciójával kapcsolatos félelmet Fülöp és Berkics (2007) „,szociális óvatosságnak” nevezték.

Az iskolai élet számos olyan versenyhelyzetet teremt, amelyböl a gyermekek vesztesként vagy győztesként kerülnek ki. A győzelem és vesztés feldolgozása meghatározó az énkép és önértékelés alakulásában (Price, 2000). Bár a versengés különböző kimeneteleinek feldolgozása különösen jelentős kisgyermekkor és serdülőkor táján a még formálódó személyiség fejlődésében, csak kevés olyan vizsgálat született, amely szisztematikusan, a maga komplexitásában és egymással való összefüggésében vizsgálná a győzelemre és vesztésre adott érzelmi, kognitív és viselkedéses reakciókat. Fülöp és Berkics (2003) magyar és angol középiskolások győzelemre és vesztésre adott reakcióit hasonlították össze nyílt kérdéses kérdőív segítségével. A magyar serdülők fontosabbnak tartották a győzelmet, a győzelem kapcsán több pozitív érzelmet (öröm, boldogság, elégedettség, büszkeség) említettek, valamint a magyar fiatalokat jobban motiválta a győzelem és gyakrabban említették annak önbizalom-növelö hatását, mint angol társaik. A vesztés kapcsán nem volt különbség az említett érzelmek arányában, de jellegükben igen. A magyar serdülők több deaktiváló érzelemről (pl. szomorúság) számoltak be, mint az angolok, akik ezzel szemben több aktiváló érzelmet említettek (pl. frusztráció). Harter (1999) serdülőkkel végzett vizsgálata összefüggést mutatott ki a kudarcról való gondolkodás és a depresszió között. Azok, akik a kudarcról való gondolkodástól rosszabbul érezték magukat, alacsony önértékelésről és reménytelenségérzésről számoltak be. Azok azonban, akik a kudarcra adott lehetséges megoldásokat ugródeszkának tekintették a változásra, alacsonyabb szintü depressziót és önmegvetést fejeztek ki. Fülöp (1992) úttalálóknak nevezte azokat a tehetséges gyermekeket, akik a kudarcokat a továbbfejlődés sarokköveinek tartották.

Fülöp és Berkics (2007) a győzelemre és vesztesre adott egymástól kvalitatíve eltérő reakciómódokat azonosítottak gimnazistákkal végzett zárt kérdőíves vizsgálatukban. A győzelem esetén kirajzolódó faktorok a következők voltak: 1. Öröm és aktiváció (a győzelem felett érzett pozitív érzelmek és energetizáló hatásuk), 2. Nárcisztikus énfelnagyitás (a győzelemmel kapcsolatos énfelnagyítás és mások lenézése), 3. Szociális óvatosság (a győzelemmel kapcsolatos negatív érzések és a szociális közeg reakciójával kapcsolatos félelmek) és 4. Elégedettség (pozitív eredmények utáni elégedett nyugalom). A vesztéssel kapcsolatban szintén négyféle reakciómód rajzolódott ki: 1. Önleértékelés (vesztes értéktelenség érzése, lecsökkent önbizalom), 2. Szomorúság és frusztráció (vesztést követő szomorúság keveredése az energiát adó haraggal és frusztrációval), 3. Agresszió a gyöztessel szemben (a vesztes legfőbb érzelmi válasza a vesztésre a győztessel szembeni harag), és 4. Háritás és deaktiválódás (a vesztes unalommal, fáradtsággal, érdektelenséggel reagál a vesztésre).

Sándor (2010) interjús vizsgálatában szintén arról számol be, hogy a győzelem és vesztés már kisiskolások számára is erősen érzelemtelített fogalmat takar. A győzelem a 8-9 éves gyermekek számára jellemzően egy örömteli, jó érzés, amelyet gyakran olyan komplex érzelmek is követnek, mint a büszkeség vagy a sikeresség érzése. A pozitív aspektusok mellett ugyanakkor a megkérdezett gyermekek 47\%-a megemlíti a győzelem esetleges interperszonális kapcsolatokat fenyegető hatását. A vesztést szintén képesek komplexen észlelni, jellemzően negatív érzéseket, szomorúságot, csalódottságot kapcsolnak hozzá, 
azonban a vesztés pozitív aspektusait is megemlítik, mint a versengés folyamatában való részvételt annak izgalmával együtt, az interperszonális kapcsolatot fókuszba helyezve a győztes örömét, valamint a vesztés olyan pozitív következményét, mint pl. az önismerethez való hozzájárulása.

A győzelemre és vesztésre adott eltérő affektív reakciók eltérő megküzdési módokkal járnak együtt, és eltérő módon befolyásolják a kognitív feldolgozás folyamatát. Baker-Ward és munkatársai (Baker-Ward, Eaton és Banks, 2005) egy ifjúsági futball mérkőzés győztes és vesztes csapatát interjúvolták meg a verseny lefolyásáról. A tíz éves gyermekek eltérő részleteit idézték fel ugyanannak az eseménynek attól függően, hogy a győztes vagy a vesztes csapat tagjai voltak. A győztes csapat tagjai gyakrabban említettek a versengés szempontjából központi információkat, amelyek döntőek a kimenetel szempontjából (pl. a mérkőzés állása), összefüggőbb beszámolót adtak az események logikai egymásutánjáról, továbbá kétszer olyan gyakran vitatták meg az eseményeket a többiekkel, mint a vesztes csapat tagjai, akik beszámolóikban nagyobb arányban adtak az eredményeket értelmező, valamint reflektív, saját belső állapotukat leíró állításokat (pl. „Nagyon jók voltak.”, „Nagyon nehéz volt veszíteni.”).

\section{A versengés iskolai szocializációja}

A versengéssel kapcsolatos gyermeki vélekedések, a győzelemmel és vesztéssel való megküzdési módok formálásában a családi szocializáció mellett az iskolai élet a legmeghatározóbb. A magyar tanárok által előszeretettel alkalmazott frontális óraszervezés kedvez a versengő, teljesítménycentrikus osztálytermi környezet kialakulásának (Halász és Lannert, 2003). A 2000-es PISA felmérés eredményei szerint a 24 részt vevő ország közül Magyarországé lett a nyolcadik legmagasabb pontszám a versengő tanulás tekintetében, melyet olyan kérdéssel vizsgáltak, hogy a diákok szeretnek-e másoknál jobban teljesíteni (a legjobbnak lenni, jobban tanulni másoknál, arra törekedni, hogy másoknál jobbak legyenek) (OECD, 2001, 4. 9. táblázat).

A diákok versengéshez való viszonyulását, a győzelemmel és vesztéssel kapcsolatban kialakított megküzdési módokat jelentősen befolyásolja, ahogyan a tanárok értelmezik és értékelik a versengési helyzeteket. Kasik és munkatársai (Kasik, 2010; Tóth és Kasik, 2010) vizsgálatában a megkérdezett 4-18 éves gyermekek szülei úgy gondolják, hogy míg az együttműködés és a segítségnyújtás módjainak elsajátítása főleg a családi nevelésen múlik, a versengő magatartás és a vezetői viselkedés formálásáért jellemzően az iskola a felelős. Annak ellenére, hogy a gyermekek nagyszámú versenyszituációban vesznek részt az iskolában, csak kevés szisztematikus vizsgálat született, amely a versengés iskolai szocializációját, a tanárok versengésről való gondolkodását célozta meg feltárni. Fülöp és munkatársai (Fülöp, Ross és mtsai, 2007) több nemzetet - magyar, angol, szlovén - érintő kulturális összehasonlító vizsgálatukban arra voltak kíváncsiak, hogy milyen koncepciók alakítják a pedagógusok hétköznapi nevelési tevékenységét az együttmüködéssel és versengéssel kapcsolatban (pl. a mindennapi munka során milyen mértékben alkalmaznak versengésre és együttmüködésre késztető módszereket az iskolában). Az eredmények szerint a magyar tanítónők adják a legtöbb versenyfeladatot, teremtik a legtöbb versenyhelyzetet, valamint leginkább buzdítanak versengésre spontán megjegyzések formájában is. Az együttmüködés terén viszont a szlovén és az angol pedagógusok adnak leggyakrabban együttmüködést igénylő csoportos feladatokat, és spontán üzeneteikkel leginkább késztetik a tanítványaikat kooperációra.

A magyar iskolarendszer erősen szelektív jellege megnövekedett eltéréshez vezet a különböző iskolák teljesítménye között (pl. OECD, 2001). Ha figyelembe vesszük, hogy az egyéni teljesítmény különbségeket az iskola mérsékelheti vagy felnagyíthatja attól függően, hogy hatékony, jól működő vagy alacsony hatékonysággal működő iskoláról beszélünk (Tóth, 
Csapó és Székely, 2010), különösen érdekessé válik az a kérdés, hogy vajon a különböző iskolák étosza hogyan kezeli a versengés kérdését, milyen mértékben alakít ki a gyermekekben megfelelő megküzdési módokat a győzelemmel és vesztéssel kapcsolatban. A kérdés aktualitása és relevanciája ellenére azonban nagyon kevés azoknak a vizsgálatoknak a száma, amelyek a versengési attitüdöt az iskola akadémikus színvonala mentén vizsgálná. Sándor (2010) 8-9 éves kisiskolással végzett vizsgálatában átlagos és magas akadémikus teljesítményü iskolákat hasonlított össze. Az eredmények alapján a magasabb akadémikus teljesítményü iskolába járó diákokra jellemzőbb volt a versengési kedv, intenzívebben és gyakrabban versengenek, valamint sikeresebbnek érzik magukat a versengésben, mint az átlagos tanulmányi színvonalú iskolába járó társaik. Egy másik vizsgálat (Pressing és Fülöp, 2011) alacsony, közép és magas tanulmányi színvonalú iskolák mentén térképezte fel az együttmüködéssel és versengéssel kapcsolatos tanári koncepciókat. Az eredmények a versengés erősen ambivalens megítéléséről számolnak be mindhárom iskolatípusban. A tanárok jellemzően természetes, veleszületett viselkedésnek tartják a versengést, amely nem igényel külön iskolai szocializációt és a tanórákon többnyire annak visszaszorítására törekszenek. A legkritikusabb, legnegatívabb attitüddel a közepes tanulmányi teljesítményü iskolák tanárai rendelkeznek. A magas tanulmányi színvonalú iskolák tanárai fordítják a legnagyobb hangsúlyt a győzelem és vesztés megfelelő kezelésére, jellemzően nem a versengés visszaszorítását választják a gyengébb képességü tanulók megóvása érdekében.

\section{Nemi különbségek a gyermekkori versengésben}

Kisiskoláskorra jelentős nemi különbségek is megfigyelhetők a versengéssel kapcsolatban (Schneider, Benenson, Fülöp és mtsai, 2011). Ruble és munkatársai (Ruble, Feldman, Boggiano, 1976) a társas összehasonlításra való igény megjelenését és alakulását vizsgáló kísérletükben azt találták, hogy az óvodáskorú és kisiskolás fiúk szignifikánsan több figyelmet fordítottak arra, hogy társukat megfigyeljék, mint a lányok. Masters (1968) illetve McClintock és Moskowitz (1976) eredményei szerint a fiúk versengő, illetve megosztó viselkedése konzisztensebben igazodik a helyzethez, mint a lányoké; kevesebbet osztanak meg versengő helyzetben, viszont többet együttmüködő helyzetben, és többet osztanak meg akkor, ha előzetesen több jutalmat kaptak. Knight és Chao (1989) 3-12 éves gyerekekkel végzett vizsgálatában a lányok inkább individualista stratégiát választottak (saját nyereményeik maximalizálása), míg a fiúk versengő stratégiát követtek (saját és a másik pontjai közötti különbség növelése). Roy és Benenson (2002) kisiskoláskorban szintén talált nemi különbséget a bőséges és szükös erőforrásokért való versengésben. Az iskolás fiúkra egyértelmüen jellemzőbb volt, hogy minden helyzetben versengtek egymással, a lányok versengési késztetéseit azonban a helyzet sajátosságai nagymértékben befolyásolták, kevésbé vettek részt a versengésben akkor, ha az erőforrások bőségesek voltak, mint akkor, ha szükösek. Green (2003) vizsgálatában a lányok még szükös erőforrások esetén is csak akkor váltak erősen versengőkké, ha lányokkal kellett megküzdeniük. Ahlgren és Johnson (1979) 818 évesekkel végzett vizsgálata szerint a fiúk minden korosztályban versengőbbnek vallották magukat, mint a lányok, és ez a különbség az életkor elörehaladtával szignifikánsan növekedett, serdülökorra a lányok már sokkal kevésbé tartották magukat versengőnek, mint kisiskoláskorban. Ugyancsak erre az életkorra tehető a lányoknál megfigyelhető sikerfélelem kialakulása (Horner, 1972), amikor a „férfiasnak" mondható területeken (pl. természettudományok) a lányok visszafogják a versengést attól való félelmükben, hogy nem fogják elég nőiesnek tartani őket.

A versengés preferálása mellett a versengés stílusában is különbség mutatkozik. A fiúkra főleg iskolás koruktól kezdve - jellemzőbb a csapatsport, valamint az olyan helyzetek 
preferálása, amikor azonos nemű társaikkal alkotnak kisebb-nagyobb csoportokat (Benenson, 1990; Benenson, Nicholson és mtsai 2001). A fiúk alkotta csoportokban fontos a dominancia hierarchia, amely elsősorban olyan látható és egyértelmü fizikai tulajdonságokon alapul, mint a fizikai erő, a gyorsaság vagy az ügyesség. A státuszért, hatalomért, területért való küzdelemben a fiúk gyakrabban választják a versengés nyílt, direkt formáit, gyakrabban alkalmaznak fizikai erőpróbát a fenti célok eléréséhez (Archer, 2006). A lányok számára jelentősebbek a személyközi kapcsolatok és a kétszemélyes barátságok (Benenson, Apostoleris és Parnass, 1998), kényelmetlenebbül érzik magukat nyílt versengési helyzetekben, mint a fiúk (Benenson és mtsai, 2001). A lányok hajlamosak az eredményt tompítani olyan játékokban, ahol a győztes és vesztes személye világosan elkülöníthető, míg a fiúk felvállalják, és sok esetben kiélezik az ezzel járó konfliktust (Lever, 1976). Sándor (2010) kisiskolásokkal végzett interjús vizsgálatában a lányok gyakrabban említették a győzelem negatív aspektusaként annak interperszonális kapcsolatokat veszélyeztető voltát, valamint gyakrabban emelték ki a vesztés pozitív interperszonális aspektusát. Más vizsgálatokból azonban kiderül, hogy a lányokra a társadalmi elvárásoknak megfelelően jellemző kedvesség mellett a fiúkéhoz hasonlóan erős és agresszív versengési késztetések élnek, melyek árnyaltabban, kevésbé látható módon jelentkeznek (Hughes és Dunn, 1998; Fülöp, 2005). A lányok tehát nem a versengési késztetés intenzitásában, hanem inkább az ezzel kapcsolatban alkalmazott - sokszor rejtett, manipulatív és indirekt - módszereikben különböznek a fiúktól (Pepitone, 1980).

\section{A vizsgálat célja}

Az eddigiek alapján látható, hogy a gyermekkori versengés jelensége sokat vizsgált területnek számít, azonban kevés azon kutatások száma, amelyek a versengés és annak kimeneteleinek gyermeki reprezentációját kívánták mélyrehatóan feltárni (pl. Fülöp, Sándor, 2008; Sándor, 2010). Az itt bemutatott vizsgálat egy kiterjedtebb kutatás része, melynek célja kisiskolás korú gyermekeknek a versengés lehetséges kimeneteleivel, a győzelemmel és a vereséggel kapcsolatos reprezentációinak feltérképezése volt. A kutatás során a jelenségek komplexebb megértése céljából triangulációt alkalmaztunk, azaz három különböző módszer - rajzvizsgálat, asszociációs módszer és klinikai interjú - segített annak feltárásában, hogy 8-9 éves kisiskolás korú gyermekek milyen fogalmi keretbe ágyazzák a versengés társas jelenségét. A versengés, győzelem és vesztés rajzokon végzett tradicionális rajzelemzés, valamint az asszociációs vizsgálat eredményeit korábbi tanulmányaink taglalják (Fülöp és Sándor, 2008; Sándor, Orosz és Fülöp, 2010). A tradicionális rajzvizsgálat (Fülöp és Sándor, 2008) során a vizsgált fogalmak a megjelenített versengés jellege és területe, a versenyhelyzet szimbólumai, valamint a megjelenített szereplők, azok mérete és az érzelmek mentén kerültek elemzésre. $\mathrm{Az}$ eredmények rámutatnak arra, hogy a rajzok többségében a gyermekek többnyire strukturált versenyhelyzetet jelenítenek meg, mely tipikusan a sporthoz kapcsolódik, és azonos nemüek között zajlik. Az érzelmek tekintetében a versengés folyamata és a győzelem tipikusan pozitív érzelmekkel jár együtt, míg a vesztés érzelmi ambivalenciát tükröz, ahol a győztes öröme mellett a vesztes bánata is világosan megnyilvánul. Az asszociációs vizsgálat (Sándor, Orosz és Fülöp, 2010) eredményei egybevágnak és megerösítik a rajzvizsgálat során nyert eredményeket. Kisiskolások a versengés fogalmát elsősorban mint versenyt, ezen belül is leginkább mint sportversenyt értelmezik, a fogalmat kevésbé kötik a legfóbb életterületeikhez, a családhoz és az iskolához. A győzelem és a vesztés érzelmileg erősen telített fogalmak számukra, a győzelem egyértelműen pozitív a vesztés pedig jellemzően negatív érzelmeket idéz.

Jelen tanulmány a győzelem és vesztés témájában adott gyermeki rajzokat a fogalmak főleg tematikus aspektusára koncentráló korábbi tradicionális rajzelemzéshez képest a vizsgált 
jelenségek interperszonális jellege mentén, a győztes és vesztes viszonyának tükrében elemzi a PAIR módszer (Pictorial Assessment of Interpersonal Relationship, Bombi, Pinto és Cannoni, 2007) segítségével.

\section{A vizsgálat résztvevői és menete}

A vizsgálatban összesen 67 gyermek vett részt: 33 fiú és 34 lány (átlagéletkor: 8,6 év), két budapesti általános iskola második osztályának tanulói. Mindkét iskolából egy-egy teljes osztály, valamint a nemi megoszlás egyenletesebbé tétele érdekében a másik párhuzamos osztályból további 10-10 gyermek alkotta a vizsgálati mintát. A vizsgálatban résztvevő két általános iskola mind az akadémiai teljesítmény, mind a szülők szocio-ökonómiai státusza szempontjából különbözött egymástól. Az átlagos akadémikus teljesítményü iskola kiválasztásánál a kerületi Pedagógiai Szolgáltató Központ segítségével olyan helyszín került kiválasztásra, ahol mind a szülők szocioökonómiai státusza, mind iskolai végzetségük megfelelt a budapesti átlagnak. A magasabb akadémikus teljesítményü iskola kiválasztásánál a gimnáziumok közötti országos rangsorra támaszkodva egy olyan fövárosi vezető gimnázium általános iskolájára esett a választás, amely intézmény évek óta a Köznevelés által kiadott országos lista első 10 helyezettje között szerepel és amelynek ,jó hírét” mind a szakma, mind az érintett szülök ismerik és elismerik. Ez utóbbi iskolába járó gyerekek szülei mind a szocioökonómiai státusz, mind az iskolai végzettség szempontjából meghaladták a budapesti átlagot.

A rajzoltatás osztálytermi környezetben csoportos helyzetben történt. A gyermekek három különböző alkalommal egy-egy rajzot készítettek a versengés, a győzelem, illetőleg a vesztés témájában. A rajzoláshoz A/4-es fehér papírt és színes ceruzát a vizsgálat vezetői biztosítottak minden gyermek számára.

Az instrukció a következőképp hangzott:

„Most mondani fogok egy szót. Arra kérlek benneteket, hogy ezzel a szóval (versengés/győzelem/vesztés) kapcsolatban rajzoljátok le azt, ami elöször eszetekbe jut. Bármit lerajzolhattok, nincs jó vagy rossz válasz, de szeretném, ha nem néznétek a szomszédotok rajzát, hanem egyedül találnátok ki, hogy mit szeretnétek rajzolni. A rajzolásra kb. 30 perc áll a rendelkezésetekre, ha bármi kérdésetek van, tegyétek fel a kezeteket és odamegyek. Jó munkát!"”

Jelen tanulmányban a gyermekeknek a versengés eltérő kimeneteleivel, a győzelemmel és vesztéssel kapcsolatos két rajzát vetettük össze négyféle összehasonlítási szempont mentén:

1. Győzelem rajzon a győztes és a vesztes viszonya

2. Vesztés rajon a győztes és a vesztes viszonya

3. A győztes ábrázolása győzelem rajzon és a győztes ábrázolása vesztés rajzon

4. A vesztes ábrázolása győzelem rajzon és a vesztes ábrázolása vesztés rajzon

A vizsgálatban alkalmazott PAIR (Bombi, Pinto és Cannoni, 2007) módszer lehetővé teszi a vizuálisan megjelenített, diádikus interperszonális kapcsolatok komplex elemzését, így jól alkalmazható eljárásnak bizonyul a győzelem és vesztés kapcsán a győztes és vesztes között fennálló társas viszonyulások gyermeki reprezentációjának mélyreható feltárásához. 
A módszer 6 fö szempont (kohézió, távolítás, hasonlóság, érték, érzelmek és konfliktus) mentén elemzi a diádikus interperszonális kapcsolatokat (1. táblázat). ${ }^{1}$

\begin{tabular}{|c|c|c|}
\hline Fő szempont & Alskálák & Tartalom \\
\hline Kohézió (C) & $\begin{array}{ll}\text { 1. } & \text { ránézés } \\
\text { 2. } & \text { közelítő mozgás } \\
\text { 3. } & \text { koordinált aktivitás } \\
\text { 4. } & \text { közelség } \\
\text { 5. } & \text { közös tér } \\
\text { 6. } & \text { egység }\end{array}$ & $\begin{array}{l}\text { ábrázolt figurák közötti kapcsolat és azok } \\
\text { közelségének megállapítása }\end{array}$ \\
\hline Távolítás (D) & $\begin{array}{l}\text { 1. elfordított tekintet } \\
\text { 2. távolító mozgás } \\
\text { 3. független aktivitás } \\
\text { 4. távoliság } \\
\text { 5. individuális tér } \\
\text { 6. elkülönülés }\end{array}$ & 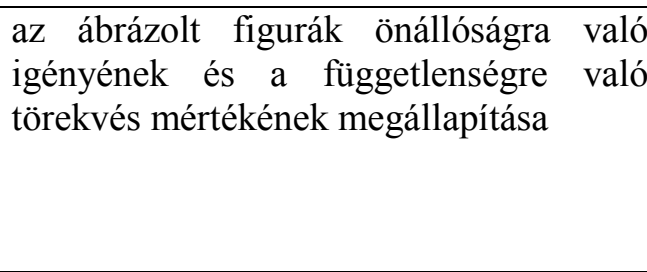 \\
\hline Hasonlóság (S) & $\begin{array}{ll}\text { 1. } & \text { magasság } \\
\text { 2. } & \text { testtartás } \\
\text { 3. } & \text { testalkat } \\
\text { 4. } & \text { kiegészítők } \\
\text { 5. } & \text { színek } \\
\text { 6. } & \text { nem }^{2}\end{array}$ & $\begin{array}{l}\text { a megjelenített figurák hasonlóságának } \\
\text { megállapítása }\end{array}$ \\
\hline Érték (V) & $\begin{array}{ll}\text { 1. } & \text { elfoglalt tér } \\
\text { 2. } & \text { dominancia } \\
\text { 3. } & \text { testrészek száma } \\
\text { 4. } & \text { kiegészítók száma } \\
\text { 5. } & \text { színek száma } \\
\end{array}$ & $\begin{array}{lrr}\text { az ábrázolt } & \text { figurák } & \text { egymáshoz } \\
\text { viszonyított } & \text { értékességének } \\
\text { megállapítása } & & \end{array}$ \\
\hline Érzelmek (E) & & $\begin{array}{l}\text { az ábrázolt figurák érzelmeinek és a rajz } \\
\text { érzelmi környezetének meghatározása }\end{array}$ \\
\hline Konfliktus (CT) & & $\begin{array}{lcl}\text { a rajz } & \text { konfliktus-telítettségének } \\
\text { megállapítása } & \end{array}$ \\
\hline
\end{tabular}

Mivel a vizsgálatban résztvevő gyermekek rajzai nem minden esetben voltak alkalmasak a PAIR módszer alkalmazásához, mert csak egy szereplöt, vagy csak a győztest vagy csak a vesztest ábrázolták, így a teljes vizsgálati anyagból végül csak a győztest és vesztest egyszerre megjelenítő 30 gyermek (14 fiú és 16 lány; 20 magas és 10 alacsony akadémikus teljesítményü iskola) rajza, tehát összesen 30 győzelem és 30 vesztés rajz képezte az elemzés alapját. $^{3}$

A Bombi és munkatársai (Bombi, Pinto és Cannoni, 2007) által kidolgozott rajzelemzési rendszerben az egyes skálák és alskálák értékelése kapcsán nincs jelentősége, hogy az adott alskálán elért pontszámok az ábrázolt társas viszonyuláson belül melyik figurához kapcsolódnak. A győzelem és vesztés reprezentációja szempontjából viszont jelentősége van annak, hogy miként ábrázolják a gyerekek a győztest és a vesztest, egy-egy értékelés melyik

\footnotetext{
${ }^{1}$ A vizsgáló eljárás részletes bemutatását lásd Sándor, Fülöp és Sebestyén (megjelenés alatt) tanulmányában.

${ }^{2}$ Az eredeti Bombi-féle vizsgáló eljárás nem tartalmazza ezt az alskálát, a versengéssel való relevanciája miatt azonban szükségesnek éreztük a kiegészitést.

${ }^{3}$ A teljes vizsgálati anyag hagyományos rajzvizsgálati módszerrel való elemzése részletesen olvasható Fülöp és Sándor (2008) tanulmányában.
} 
szereplöre vonatkozik. Ezért a PAIR-értékeléseket, ahol ennek jelentősége volt, mindkét szereplöre elvégeztük és megvizsgáltuk, hogy a győztesekhez, illetve a vesztesekhez milyen arányban kapcsolódnak a releváns alskálákon elért pontszámok.

\section{Eredmények}

$\underline{\text { Kohézió (C) és Távolítás (D) skálák szerinti értékelés }}$

Bár a Kohézió és Távolítás skálák egymástól függetlenül kerülnek értékelésre, az eredmények értelmezése egymással összefüggésben lehetséges. A győzelemmel és vesztéssel kapcsolatos rajzok Kohézió $(\mathrm{C})$ és Távolítás (D) skálán kapott értékei a 2. táblázatban láthatóak. Mivel mindkét skála dichotóm és 6-6 alskálából áll, az egyes skálákra kapható pontszámok 0 és 6 között helyezkednek el. Minél magasabb az érték, annál kifejezettebb a figurák közötti összetartozás (Kohézió) illetve a figurák függetlenségre való törekvésének (Távolítás) kifejezése.

\begin{tabular}{|c|c|c|c|c|}
\hline \multirow{2}{*}{} & \multicolumn{2}{|c|}{ Győzelem } & \multicolumn{2}{c|}{ Vesztés } \\
\cline { 2 - 5 } & $\begin{array}{c}\text { Kohézió (C) } \\
\text { átlag (szórás) }\end{array}$ & $\begin{array}{c}\text { Távolítás (D) } \\
\text { átlag (szórás) }\end{array}$ & $\begin{array}{c}\text { Kohézió (C) } \\
\text { átlag (szórás) }\end{array}$ & $\begin{array}{c}\text { Távolítás (D) } \\
\text { átlag (szórás) }\end{array}$ \\
\hline Összes (N=30) & $3,73(1,05)$ & $3,13(1,43)$ & $2,77(1,19)$ & $3,10(1,18)$ \\
\hline Fiú (N=14) & $3,79(1,05)$ & $3,36(1,44)$ & $2,64(1,21)$ & $3,14(1,36)$ \\
\hline $\begin{array}{c}\text { Lány (N=16) } \\
\text { Magas akadémikus } \\
\text { teljesítményú iskola } \\
\text { (N=20) }\end{array}$ & $3,69(1,07)$ & $3,00(1,43)$ & $2,88(1,20)$ & $3,06(1,03)$ \\
\hline $\begin{array}{c}\text { Átlagos akadémikus } \\
\text { teljesítményú iskola } \\
\text { (N=10) }\end{array}$ & $3,70(1,25)$ & $3,30(1,47)$ & $2,40(1,17)$ & $2,60(1,08)$ \\
\hline
\end{tabular}

2. Táblázat - A győzelemmel és a vesztéssel kapcsolatos rajzok értékelése a Kohézió (C) és Távolítás (D) skála alapján

A teljes minta alapján sem a győzelem sem a vesztés rajzokon nem volt szignifikáns különbség a Kohézió (C) és a Távolítás skála (D) értékei között (győzelem:t(29)=1,649; $\mathrm{p}>0,05$; vesztés: $\mathrm{t}(29)=-1,170 ; \mathrm{p}>0,05)$.

A győzelemmel és a vesztéssel kapcsolatos rajzokat, vagyis a szituációkat összehasonlítva azonban szignifikáns különbség található: a győzelemmel kapcsolatos rajzok a Kohézió (C) skálán magasabb pontszámot értek el, mint a vesztés rajzok $(\mathrm{t}(29)=3,537 ; \mathrm{p}<0,05)$. A győzelmet helyezve a fókuszba, az összetartás a győztes és a vesztes között kifejezettebb, mint akkor, ha a vesztés kerül a fókuszba. A Távolítás skála mentén nem volt szignifikáns különbség $(\mathrm{t}(29)=0,126 ; \mathrm{p}>0,05)$.

Az eredeti PAIR elemzésben a Kohézió (C) és a Távolítás (D) skála C1 és D1 alskálája, amely azt jelzi, hogy az egyik figura látja-e a másikat (C1), illetve elfordul-e a másiktól (D1) a figurákat a szituációban betöltött szerepüktől (győztes, ill. vesztes) függetlenül vizsgálja. A versengés és a társas összehasonlítás szempontjából azonban nem elhanyagolható a társas 
összehasonlítás iránya, és annak kölcsönössége sem. Ezért az elemzést kiegészítendő meg kellett vizsgálni, hogy a győztesekhez illetve a vesztesekhez milyen arányban kapcsolódnak a releváns alskálán elért pontszámok.

A C1 alskálán a 30 győzelemmel kapcsolatos rajz közül összesen 18, a 30 vesztéssel kapcsolatos rajz közül pedig 14 olyan található, amelyen legalább az egyik figura látómezejében benne van a másik, vagyis legalább az egyik figura látja a másikat $(\mathrm{C} 1)$. Ez a bizonyos figura a győzelem rajzok 88\%-ában (16 rajz), míg a vesztéshez kapcsolódó rajzok $71 \%$-ában (10 rajz) konzekvensen a győztes, tehát a győztes látja a vesztest. A D1 alskála tekintetében a győzelemmel kapcsolatos rajzok közül 21, míg a vesztéssel kapcsolatban 14 esetben áll fenn, hogy legalább az egyik figura nem láthatja a másikat. A győzelem rajzok 71\%-ában (15 rajz), míg a vesztéshez kapcsolódó rajzok 57\%-ában (8 rajz) a vesztes nem látja a győztest. Tehát szituációtól függetlenül a győztes az, aki látja a vesztest. A tekintet irányával kapcsolatos észrevételeket az 1.a és 1.b rajzok szemléltetik.

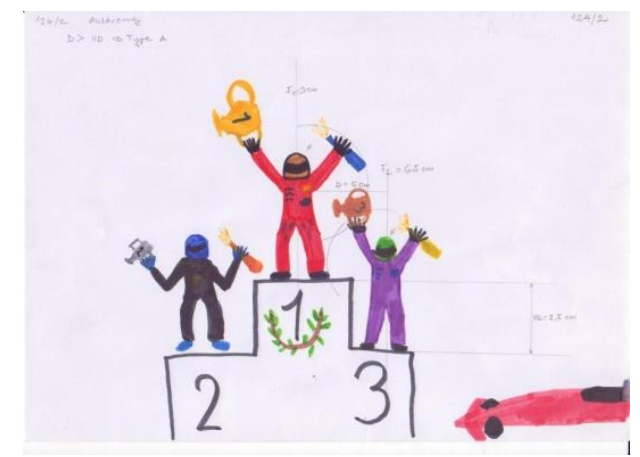

1.a Győzelem rajz

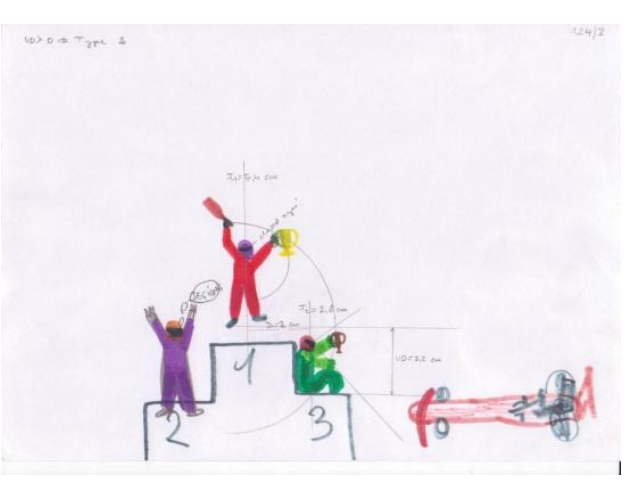

1.b Vesztés rajz

Ugyanannak a gyermeknek a győzelemhez (1.a) és vesztéshez kapcsolódó rajza (1.b). A győztes látómezejében mindkét esetben benne van a vesztes, míg a vesztes egyik esetben sem lát rá a győztesre, mivel a dobogó alsó fokán áll, továbbá a vesztés fókuszú rajz esetében a vesztes elfordulása a szituációtól (eltérő irányba néz) még kifejezettebb.

\section{Nemi különbségek}

A Kohézió (C) és a Távolítás (D) skálán nem volt nemi különbség a fiúk és a lányok között sem a győzelem, sem a vesztés esetén. A fiúk esetében a győzelem és vesztés rajzok Kohézió (C) eredményei szignifikánsan különböztek, vagyis a győzelem esetén nagyobb volt a kohézió a győztes és vesztes között, mint a vesztés esetén $(\mathrm{t}(28)=2,402 ; \mathrm{p}<0,05)$. A lányok vesztés rajzaira vonatkozó Kohézió érték szintén alacsonyabb a győzelem rajzra vonatkozóénál, a különbség azonban nem szignifikáns $(\mathrm{t}(28)=1,812 ; \mathrm{p}>0,05)$.

A Kohézió (C) és a Távolítás (D) skála C1 és D1 alskálája (a tekintet iránya) alapján a fiúk és a lányok rajzai a győzelem és a vesztés kezelésével kapcsolatban más-más stratégiát jeleznek. Mind a győzelemmel, mind a vesztéssel kapcsolatos helyzetekben a fiúk ritkábban irányítják aktívan figuráik tekintetét (győzelem: 29\%, 14-ből 4 rajz, vesztés: 43\%, 14-böl 6 rajz), jellemzően inkább „kinéznek” a rajzokról és nem egymást figyelik.

A különbség ugyan nem szignifikáns, azonban a lányok rajzain mind a győzelemmel, mind a vesztéssel kapcsolatban gyakrabban irányított a figurák tekintete (győzelem: 62\%, 16-ból 10 rajz, vesztés: 56\%, 16-ból 9 rajz). A lányok esetében a győzelem kapcsán gyakrabban „látják” a győztesek az adott győzelmi helyzetet, vagyis győztesként szembesülhetnek az eredménnyel és pozitívan kerülhetnek ki az adott összehasonlítási folyamatból. 


\section{Iskolatipus szerinti különbségek}

A magasabb akadémikus teljesítményü iskolába járó gyerekek vesztéssel kapcsolatos rajzaikon jellemzőbben izolálják a vesztest és nagyobb távolságra helyezik a győztestől, mint az átlagos akadémikus színvonalú iskolába járó társaik (tendencia szintủ szignifikancia $\mathrm{t}(28)=$ $1,727 ; p<0,1)$. Az egyes iskolatípusokon belül statisztikailag igazolható különbséget sem egy adott szituációban, sem a szituációk között nem lehetett kimutatni. A tekintet irányával kapcsolatban szintén nem mutatkozott különbség iskolák mentén.

\section{Hasonlóság-skála (S)}

A Hasonlóság (S) skála egyes alskáláin elérhető pontok értéke 0-2 között lehet. Mivel a Hasonlóság (S) skálán elérhető eredmény az egyes alskálák összeadása során alakul ki, ezért a skálák összértéke a 0-10 közötti tartományba esik. A magasabb pontszám nagyobb hasonlóságot jelent. Az eredményeket a 3. Táblázat foglalja össze.

\begin{tabular}{|l|c|c|}
\hline \multicolumn{1}{|c|}{$\begin{array}{c}\text { Hasonlóság skála (S) } \\
\mathbf{( 0 - 1 0 )}\end{array}$} & $\begin{array}{c}\text { Győzelem } \\
\text { átlag (szórás) }\end{array}$ & $\begin{array}{c}\text { Vesztés } \\
\text { átlag (szórás) }\end{array}$ \\
\hline Összes (N=30) & $4,23(1,77)$ & $4,71(1,96)$ \\
\hline Fiú (N=14) & $4,21(1,84)$ & $5,28(1,63)$ \\
\hline Lány (N=16) & $4,25(1,77)$ & $4,18(2,13)$ \\
\hline $\begin{array}{l}\text { Magas akadémikus } \\
\text { teljesítményú iskola (N=20) }\end{array}$ & $4,40(1,84)$ & $5,05(2,01)$ \\
\hline $\begin{array}{l}\text { Átlagos akadémikus } \\
\text { teljesítményú iskola }(\mathbf{N = 1 0})\end{array}$ & $3,90(1,66)$ & $4,00(1,76)$ \\
\hline
\end{tabular}

3. Táblázat - A győzelemmel kapcsolatos rajzok értékelése a Hasonlóság (S) skála alapján

A vesztés rajzok esetében ugyan hasonlóbbnak ábrázolták a figurákat a gyermekek, azonban a különbség nem szignifikáns $(\mathrm{t}(28)=0,126 ; \mathrm{p}>0,05)$ a teljes mintára vonatkozóan.

\section{Nemi különbségek}

A fiúk esetében a vesztés rajzokon az ábrázolt győztesek és vesztesek inkább hasonlítanak egymásra, mint a győzelemmel kapcsolatos rajzokon. Ez a különbség tendencia-szinten szignifikáns $(\mathrm{t}(13)=-1,883 ; \mathrm{p}<0,1)$.

\section{Iskolatípus szerinti különbségek}

A győzelemmel és a vesztéssel kapcsolatban megjelenített győztes és vesztes figurák hasonlósága tekintetében nincs szignifikáns különbség az iskolatípus mentén $(\mathrm{t}(28)=0,798$; $\mathrm{p}>0,05)$.

\section{Érték-skála (V)}

Az Érték-skála (V) esetében minden egyes rajzon meg kell határozni a megjelenített figurák Egyéni Dominancia Értékét (EDÉ). Ez az EDÉ érték az adott összehasonlítási dimenzió 
mentén tükrözi azt, hogy a gyermek a megjelenített figurákat egymáshoz képest milyen értékekkel ruházta fel, vagyis az adott összehasonlítási dimenzió mentén melyiket értékelte magasabbra és mekkora a két figura között megjelenő érték-különbség (4. táblázat). Az egyes figurákhoz tartozó EDÉ értékek az egyes alskálák értékeinek összesítése során alakulnak ki. Mivel az Érték-skála (V) öt alskálából áll, melyek mindegyikére 0-tól 2 pont adható, ezért az öt alskála összeadása után az EDÉ értéke minden esetben a 0-10-ig terjedő tartományba kerül, ahol a magasabb érték nagyobb értékkülönbséget jelent.

\begin{tabular}{|c|c|c|c|c|}
\hline \multirow{2}{*}{$\begin{array}{l}\text { A győzelemmel és a vesztéssel } \\
\text { kapcsolatos rajzokon belüli EDÉ } \\
\text { értékek összehasonlítása }\end{array}$} & \multicolumn{2}{|c|}{ Győzelem } & \multicolumn{2}{|c|}{ Vesztés } \\
\hline & $\begin{array}{c}\text { Győztes } \\
\text { EDÉ érték } \\
\text { átlag (szórás) }\end{array}$ & $\begin{array}{c}\text { Vesztes } \\
\text { EDÉ érték } \\
\text { átlag (szórás) }\end{array}$ & $\begin{array}{c}\text { Győztes } \\
\text { EDÉ érték } \\
\text { átlag (szórás) }\end{array}$ & $\begin{array}{c}\text { Vesztes } \\
\text { EDÉ érték } \\
\text { átlag (szórás) }\end{array}$ \\
\hline Összes $(\mathrm{N}=30)$ & $5,73(1,98)$ & $2,40(1,13)$ & $4,33(1,91)$ & $2,43(1,56)$ \\
\hline Fiú $(\mathbf{N}=14)$ & $4,71(1,28)$ & $1,71(1,25)$ & $4,07(1,45)$ & $2,07(1,76)$ \\
\hline Lány $(\mathrm{N}=16)$ & $6,63(1,11)$ & $3,00(1,45)$ & $4,56(1,89)$ & $2,75(1,23)$ \\
\hline $\begin{array}{l}\text { Magas akadémikus } \\
\text { teljesítményü iskola }(\mathbf{N}=\mathbf{2 0})\end{array}$ & $5,50(1,18)$ & $2,60(1,08)$ & $3,95(1,13)$ & $2,25(1,43)$ \\
\hline $\begin{array}{l}\text { Átlagos akadémikus } \\
\text { teljesítményủ iskola }(\mathrm{N}=10)\end{array}$ & $6,20(1,22)$ & $2,00(1,12)$ & $5,10(1,88)$ & $2,80(1,48)$ \\
\hline
\end{tabular}

4. táblázat. A győzelem, valamint a vesztés szituációban ábrázolt győztesek és vesztesek összehasonlítása az Érték (V) skála alapján

A teljes minta tekintetében a szituációkon belül, tehát mind a győzelemmel, mind a vesztéssel kapcsolatos rajzokon a gyerekek a győztes figurát ábrázolták dominánsabb pozícióban. A páros t-próba alapján a győzelem, illetve a vesztés rajzokon megjelenített győztes és vesztes figurákhoz tartozó EDÉ értékek közti különbség mindkét esetben szignifikáns (győzelem: $\mathrm{t}(29)=9,799 ; \quad \mathrm{p}<0,01$; vesztés: $\mathrm{t}(29)=3,936 ; \quad \mathrm{p}<0,01)$. A győzelemmel kapcsolatban megjelenített Érték különbség (GyőztesEDÉ - VesztesEDÉ) a legkifejezettebb (győzelem:3,33; vesztés: 1,90), legértékesebbnek a győzelemmel kapcsolatban megjelenített győztes figurát ábrázolják.

\section{Nemi különbségek}

A lányok a győzelem rajzokon szignifikánsan nagyobb EDÉ értékkel ábrázolták a győztest, mint a fiúk (győzelem: $t(28)=-2,969) ; p<0,01$ ).

A fiúk és a lányok által megjelenített figurák nem csupán a hozzájuk kapcsolódó értékek mentén különböznek egymástól, hanem abban is, hogy ezeket az értékkülönbségeket milyen eszközökkel fejezik ki. A fiúkra jellemző, hogy győzelem esetén a győztes figurát részletesebben dolgozzák ki $(\mathrm{F}(16,341)=2,368 ; \mathrm{p}<0,05)$ és több győzelemre utaló attribútummal (korona, kupa, érem) ruházzák fel $(\mathrm{F}(28)=-3,729 ; \mathrm{p}<0,01)$, míg a lányok inkább 
annak felnagyításával és dominánsabb pozícióba helyezésével fejezik ki (tendencia szintü különbség $F(19,351)=-1,863 ; p<0,1)$ az értékkülönbségeket.

\section{Iskolatípus szerinti különbségek}

Mind a magasabb, mind az átlagos akadémikus teljesítményü iskolába járó gyerekekre jellemző, hogy a győzelemmel kapcsolatos rajzaikon megjelenített győzteseket szignifikánsan magasabb értékkel ruházzák fel, mint az ugyanezeken a rajzokon megjelenített vesztes figurákat (magas: $\mathrm{t}(9)=2,601 ; \mathrm{p}<0,05$ és átlagos: $\mathrm{t}(9)=7,088 ; \mathrm{p}<0,01$ ). A gyözelemmel kapcsolatos rajzokon az átlagos iskolába járó gyerekek győztes és vesztes figurái között kifejezettebb az ábrázolt értékkülönbség, mint a magasabb tanulmányi teljesítményü iskolába járó gyerekek rajzain (átlagos: 4,2; magas: 2,9). A vesztéssel kapcsolatban a figurák közötti értékkülönbség a győztes javára csak az átlagos iskolába járó gyerekek rajzain szignifikáns $(t(9)=3,023 ; p<0,05)$.

A megjelenitett gyöztesek és vesztesek összehasonlitása a rajzok egymásra vetítésével

A különböző szituációkban megjelenített azonos szereplők összehasonlítása (győzelemgyőztes és vesztés-győztes; győzelem-vesztes és vesztés-vesztes) csak az Érték (V) skálája alapján végezhető el, mert ezen skála Egyéni Dominancia Értékei (EDÉ) teszik lehetővé a rajzok ilyen célú egymásra vetítését. A két szituációban meghatározott EDÉ értékek egymásra vetítése után kapott értékeket az 5. táblázat összesíti.

Természetesen az egyes figurákhoz tartozó eredeti EDÉ értékeknek az egymásra vetítés során részben változniuk kellett. A V1 alskálához tartozó győztes és vesztes EDÉ értékek - amelyek a figurák egymáshoz viszonyított magasságát jelentik - valamint a V2 alskálához tarozó EDÉ értékek, amelyek a figurák az adott lapon egymáshoz képest való elhelyezkedésére vonatkoznak - az egymásra vetítés következtében változtak, míg a másik három alskálának az egyes figurákkal kapcsolatos EDÉ értékei változatlanok maradtak, csak az összehasonlítási dimenzió változott meg. Mivel a V3, V4 és V5 alskálák alapján az egyes figurákat testrészeik száma, attribútumaik és az alkalmazott színek száma alapján az egyes rajzokon belüli összehasonlítás kapcsán már osztályokba soroltuk, így az egymásra vetítés során ezek az értékek újra használhatóak voltak, csak ezúttal nem egymással, hanem a másik rajzon megjelenített győztessel illetve vesztessel kellett elvégezni az összehasonlítást.

\begin{tabular}{|c|c|c|c|c|}
\hline $\begin{array}{c}\text { Az egymásra vetítés } \\
\text { következtében kialakult győztes } \\
\text { és vesztes figurákhoz tartozó } \\
\text { EDÉ értékek }\end{array}$ & \multicolumn{2}{|c|}{ Győztesek EDÉ értéke } & \multicolumn{2}{c|}{ Vesztesek EDÉ értéke } \\
\cline { 2 - 5 } & $\begin{array}{c}\text { Gyózelem } \\
\text { átlag (szórás) }\end{array}$ & $\begin{array}{c}\text { Vesztés } \\
\text { átlag (szórás) }\end{array}$ & $\begin{array}{c}\text { Gyózelem } \\
\text { átlag (szórás) }\end{array}$ & $\begin{array}{c}\text { Vesztés } \\
\text { átlag (szórás) }\end{array}$ \\
\hline Összes (N=30) & $5,40(1,23)$ & $3,70(1,18)$ & $3,53(1,17)$ & $3,70(1,26)$ \\
\hline Fiú (N=14) & $5(1,12)$ & $3,36(1,56)$ & $3,36(1,33)$ & $3(1,78)$ \\
\hline Lány (N=16) & $5,75(1,71)$ & $4(1,82)$ & $3,69(1,38)$ & $4,31(1,67)$ \\
\hline $\begin{array}{c}\text { Magas akadémikus } \\
\text { teljesítményú iskola (N=20) }\end{array}$ & $5,60(1,77)$ & $3,40(1,58)$ & $4,10(1,78)$ & $3,00(1,29)$ \\
\hline
\end{tabular}




\begin{tabular}{|l|l|l|l|l|}
\cline { 2 - 4 } $\begin{array}{c}\text { Átlagos akadémikus } \\
\text { teljesítményú iskola }(\mathbf{N}=10)\end{array}$ & $5,00(1,91)$ & $4,30(1,66)$ & $2,40(1,09)$ & $5,10(1,17)$ \\
\hline
\end{tabular}

5. Táblázat - A győzelemmel és a vesztéssel kapcsolatos rajzokon megjelenített győztesek és vesztesek összehasonlítása az Érték (V) skálája alapján

A minta egészét tekintve a győzelemmel kapcsolatos rajzokon megjelenített győztes figurához kapcsolódó Egyéni Dominancia Érték (EDÉ) szignifikánsan magasabb, mint a vesztéssel kapcsolatos rajzokon megjelenített győztes figuráé $(t(29)=3,061 ; p<0,01)$. A győzelemmel és a vesztéssel kapcsolatban megjelenített vesztes figurák EDÉ értékei között nincs szignifikáns különbség $(\mathrm{t}(28)=0,147 ; \mathrm{p}>0,05)$.

\section{Nemi különbségek - A rajzok egymásra vetítése}

A két különböző helyzetben ábrázolt győztesek megjelenítésében mindkét nem a győzelem szituációban megrajzoltat mutatta értékesebbnek, szignifikáns különbséget azonban csak a fiúk rajzain találunk $(\mathrm{t}(13)=2,203 ; \mathrm{p}<0,05)$, a lányokénál az eltérés tendenciaszintü $(t(15)=2,098 ; \mathrm{p}<0,1)$, vagyis a lányok által a két különböző helyzetben ábrázolt győztesek hasonlóbbak, mint a fiúk rajzain.

A vesztes figurákkal kapcsolatban fentebb már leírt minimális értékkülönbség mögött jelentős nemi különbség található. Míg a fiúk - ha minimális mértékben is, de a győzelemmel kapcsolatban megjelenített vesztes figurát ábrázolták értékesebbnek (győzelem-3,36 versus vesztés-3,03), addig a lányoknál a tendencia megfordult, és ők a vesztéssel kapcsolatban megjelenített vesztest helyezték értékesebb pozícióba (győzelem-3,69 versus vesztés-4,32). Mindennek következtében, míg a győzelemmel kapcsolatban megjelenített vesztesek pozíciója a fiúk és a lányok rajzain alig különbözik (fiúk-3,36 versus lányok-3,69), addig a vesztéssel kapcsolatban megjelenített vesztesek esetén a lányok vesztesei tendencia szinten dominánsabb pozícióban vannak, mint a fiúk vesztesei $(\mathrm{t}(15)=2,027 ; \mathrm{p}<0,1)$.

\section{Iskolatípus szerinti különbségek - A rajzok egymásra vetitése}

A magasabb akadémikus teljesítményü iskolába járó gyerekek rajzaira jellemző, hogy a győzelemmel kapcsolatban megjelenített győztesek pozíciója szignifikánsan magasabb, mint a vesztés rajzokon megjelenített győzteseké $(\mathrm{t}(19)=2,994 ; \mathrm{p}<0,01)$. Ezzel szemben az átlagos tanulmányi színvonalú iskolába járó gyerekek kétféle helyzetben megjelenített győztesei között nincs szignifikáns érték-különbség $(\mathrm{t}(19)=0,189 ; \mathrm{p}>0,05)$.

Az iskolatípus tekintetében a két különböző helyzetben megjelenített vesztes figurák között is különbség található. A magasabb akadémikus teljesítményü iskolába járó gyerekek a győzelemmel kapcsolatban szignifikánsan értékesebb pozícióban ábrázolják vesztest, mint a vesztéssel kapcsolatban $(\mathrm{t}(28)=-3,230 ; \mathrm{p}<0,01)$, az átlagos iskolába járó gyerekek rajzain a vesztéssel kapcsolatban megjelenített vesztes van értékesebb pozícióban $(\mathrm{t}(28)=2,899$; $\mathrm{p}<0,01)$.

\section{$\underline{\text { Érzelem-skála }(\mathrm{E})}$}

Az Érzelem-skálára vonatkozó (E) elemzés során a győztesek és vesztesek által kifejezett érzelmek kerültek kategorizálásra, melynek eredményei az 1.a, 1.b ábrákon láthatók. 

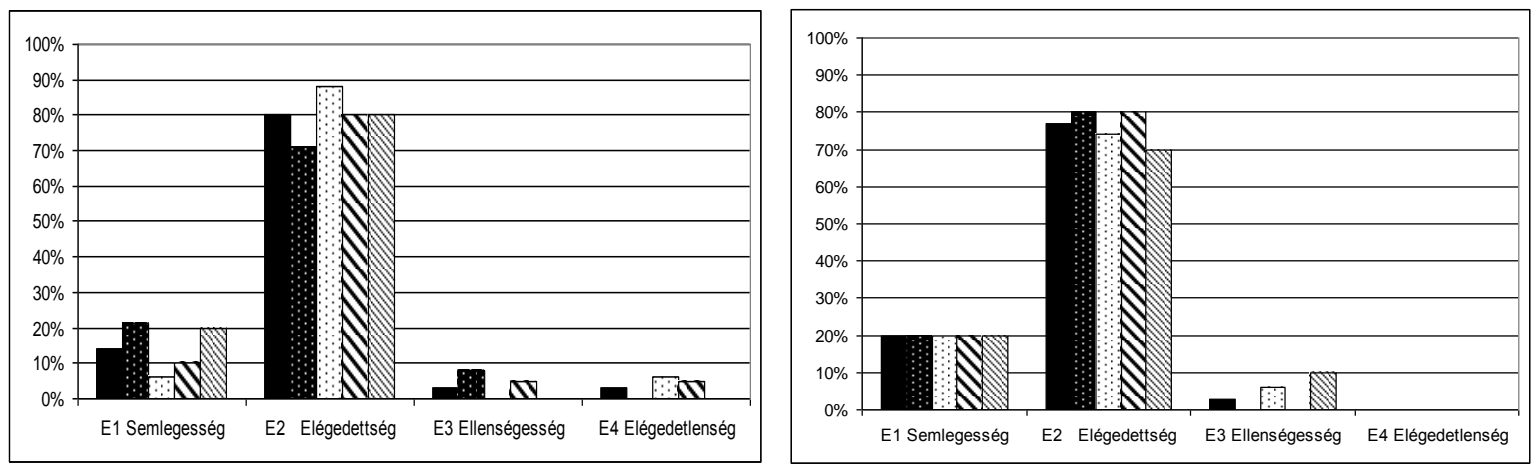

1.a ábra A győztesek érzelemkifejezése a győzelemmel (bal) és vesztéssel (jobb) kapcsolatos rajzokon
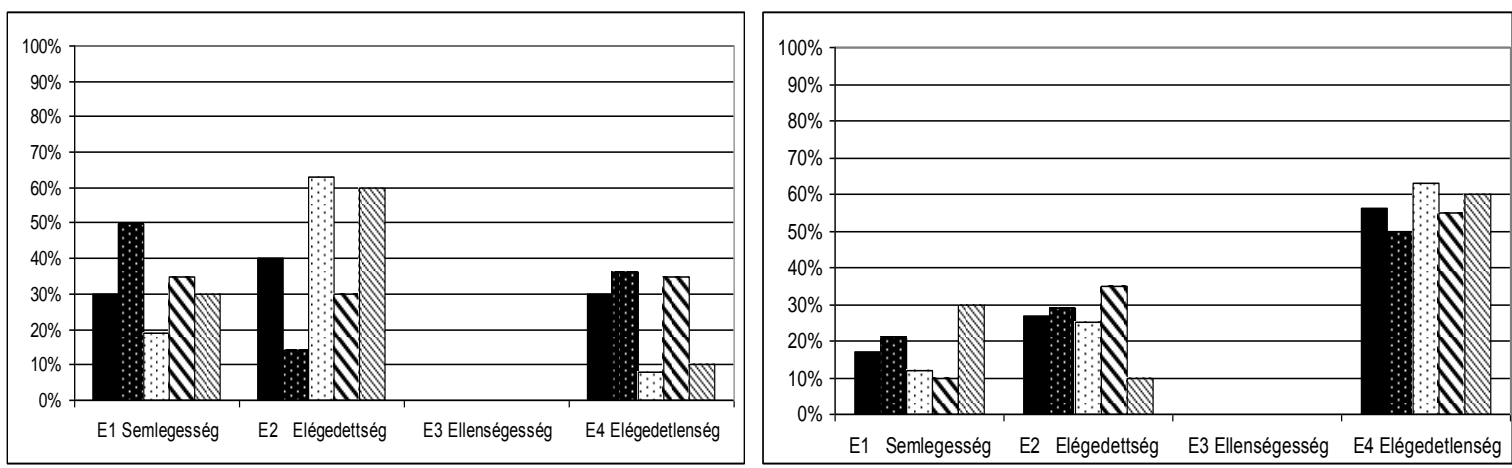

1.b ábra A vesztesek érzelemkifejezése a győzelemmel (bal) és vesztéssel (jobb) kapcsolatos rajzokon

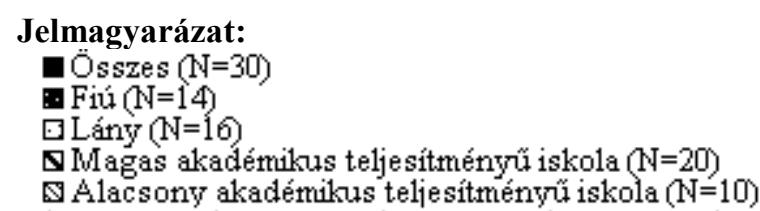

A győzelemmel kapcsolatos rajzok 80\%-ban a győztesek elégedettséget fejeznek ki, a gyerekek szignifikánsan több pozitív érzelmi kifejezést - mosolyt, nevetést, magasra tartott kezeket - társítottak a győztes figurához (khi négyzet $(3)=49,200 ; p<0,01)$, mint más egyéb érzelmet (1.a ábra). Érzelemmentesen (14\%) vagy ellenségesen (3\%), elégedetlenül $(3 \%)$ elvétve ábrázolják a győztest. A vesztéssel kapcsolatban megjelenített győztesek érzelemkifejezése hasonló mintázatot mutat. A vesztés rajzok $77 \%$-ában is leginkább elégedettnek ábrázolták a győztest, ez lesz a legjellemzőbb érzelem (khi négyzet (2) $=26,600$; $\mathrm{p}<0,01)$. Érzelmek nélkül vagy ellenségesen vesztés esetén is csak kis százalékban jelenítették meg a győzteseket $(20 \% ; 3 \%)$.

A vesztesek érzelemkifejezésének ábrázolása megosztottabb képet mutat. A győzelemmel kapcsolatban megjelenített vesztesek a rajzok 40\%-ában elégedettséget, 30\%-ában elégedetlenséget fejeznek ki, továbbá 30\%-ánál nem mutatnak érzelmet. A vesztés fókuszú rajzok veszteseinek ábrázolása szintén hasonlóságot mutat a győzelem rajzokkal az érzelemkifejezés változatossága tekintetében, azonban a győzelem rajzokhoz képest itt az elégedetlenség érzése nő (56\%), míg a pozitív érzelemkifejezés (27\%) és az érzelemmentesség megjelenítése csökken $(17 \%)$. A két szituációban megjelenített vesztesek érzelemkifejezése között nem találunk szignifikáns különbséget (khi négyzet $(2)=4,404$; $\mathrm{p}>0,05)$. Szituáción belül a vesztéssel kapcsolatban megjelenített vesztes esetében az elégedetlenség kifejezése volt a legjellemzőbb érzelem $(\mathrm{khi}$ négyzet $(2)=7,800 ; \mathrm{p}<0,05)$. A 
vesztesek ábrázolása esetén nem találtunk az ellenséges érzelmekre utaló vizuális jelet. A 2 . és 3. rajz a győzelemmel és vesztéssel kapcsolatban megjelenített figurák érzelemkifejezését szemlélteti.

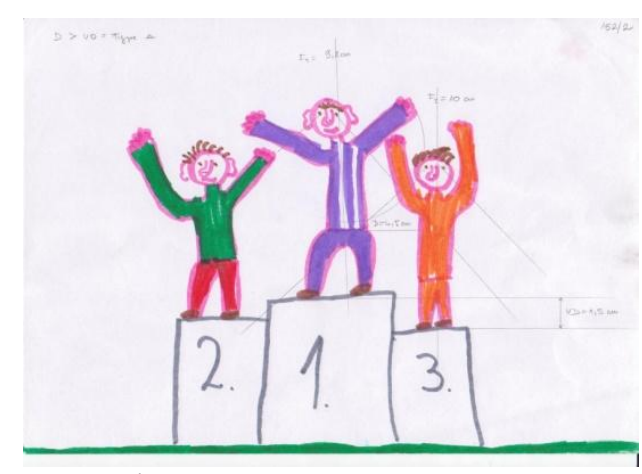

2.Győzelem rajz

A 2. rajzon a győzelemmel kapcsolatban megjelenített figurák láthatóak, a győztes elégedettsége (felfelé görbülő száj, levegöbe emelt kezek) mellett a vesztes (3. helyezett) is fejez ki örömöt (levegőbe emelt kezek). A 3. vesztés rajzon a vesztes elégedetlensége erőteljesebben ábrázolt (könnyek, lefelé görbülő száj, test előtt összezárt kezek).

\section{Nemi különbségek}

A győzelem esetén megjelenített vesztes figura ábrázolásában szignifikáns nemi különbség mutatkozott; a semleges érzelem kifejezésének megjelenítése jellemzőbb a fiúkra (Goodman Kruskal tau=2,86; $\mathrm{p}<0,05$ ), míg a pozitív érzelmek megjelenítése a lányok rajzaira (Goodman - Kruskal tau=2,44; $<<0,05)$.

A lányok továbbá érzékenyebben reagáltak a szituációk közötti különbségre; a vesztes figurát a vesztéssel kapcsolatban szignifikánsan elégedetlenebbnek ábrázolták, mint a győzelemmel kapcsolatban (Goodman - Kruskal tau=3,01; $<<0,05$ ),

\section{Iskolatípus szerinti különbség}

A különböző érzelmi kategóriák megjelenítésében nem volt szignifikáns iskolatípusok szerinti eltérés. Tendenciaszintü különbség mutatkozott azonban a szituációk mentén az átlagos akadémikus teljesítményü iskolába járó gyermekek vesztes-ábrázolásában; elégedettebbnek ábrázolták a vesztest a győzelem fókuszú rajzokon (Goodman - Kruskal tau=1,99; p<0,1), mint a vesztés témájú rajzokon, ahol az elégedetlenség kifejezése volt jellemzőbb a vesztesre (Goodman - Kruskal tau=1,99; $\mathrm{p}<0,1)$.

\section{$\underline{\text { Konfliktus-skála (CT) }}$}

A konfliktus-skála a rajz konfliktus-telitettségének megállapítására szolgál. Az elemzés során elöször azt kellett meghatározni, hogy az egyes figurák jelenítenek-e meg bármilyen jellegü konfliktust. Ha konfliktus egyik figurával kapcsolatban sem jelenik meg, akkor a rajz 0 pontot kap, amennyiben bármilyen jellegű konfliktus észlelhető a rajzon, akkor a konfliktus mértéke alapján a rajzok kategóriába sorolódnak (Lehetséges véleménykülönbség, Ellentét, Agresszió, Szakítás) és 1-4-ig pontozódnak. A 4. és 5. rajz a győzelemmel és a vesztéssel kapcsolatban megjelenített konfliktus-kategóriákat szemléleti. A konfliktus meglétét, illetőleg intenzitását 
tekintve a 30-30 győzelem és vesztés rajz esetén szituációnként egy 0-120 pontig terjedő értékintervallumot kapunk, ahol a nagyobb érték erösebb konfliktust tükröz (2. ábra).

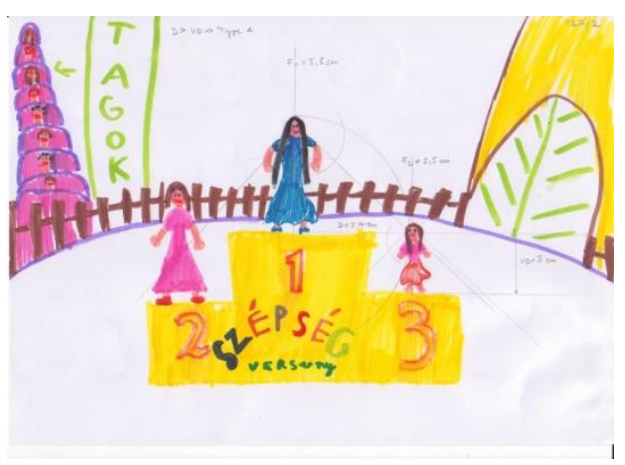

4. Győzelem rajz

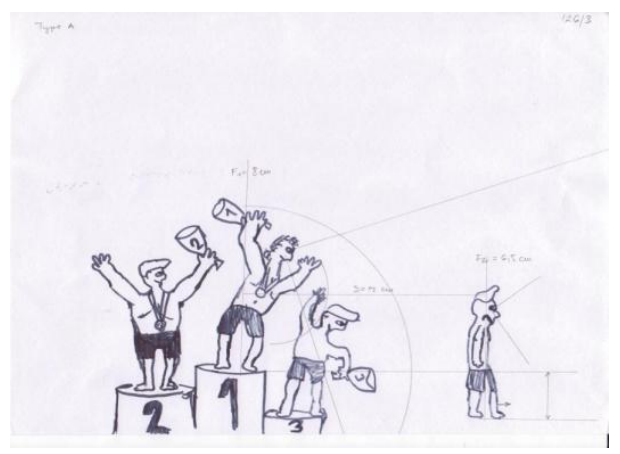

5. Vesztés rajz

A 4. rajzon, a győzelemmel kapcsolatban megjelenített győztes és vesztes figurák (3. helyezett) között nem mutatkozik konfliktus, ezért a Nincs konfliktus kategóriába (0 pont) kerül. Az 5. rajzon a győztes fenyegetően, „elüző” gesztussal fordul a képből kifelé tartó vesztes felé, ezért ez a rajz az Agresszió kategóriába kerül, és 3 konfliktus-pontot kap.

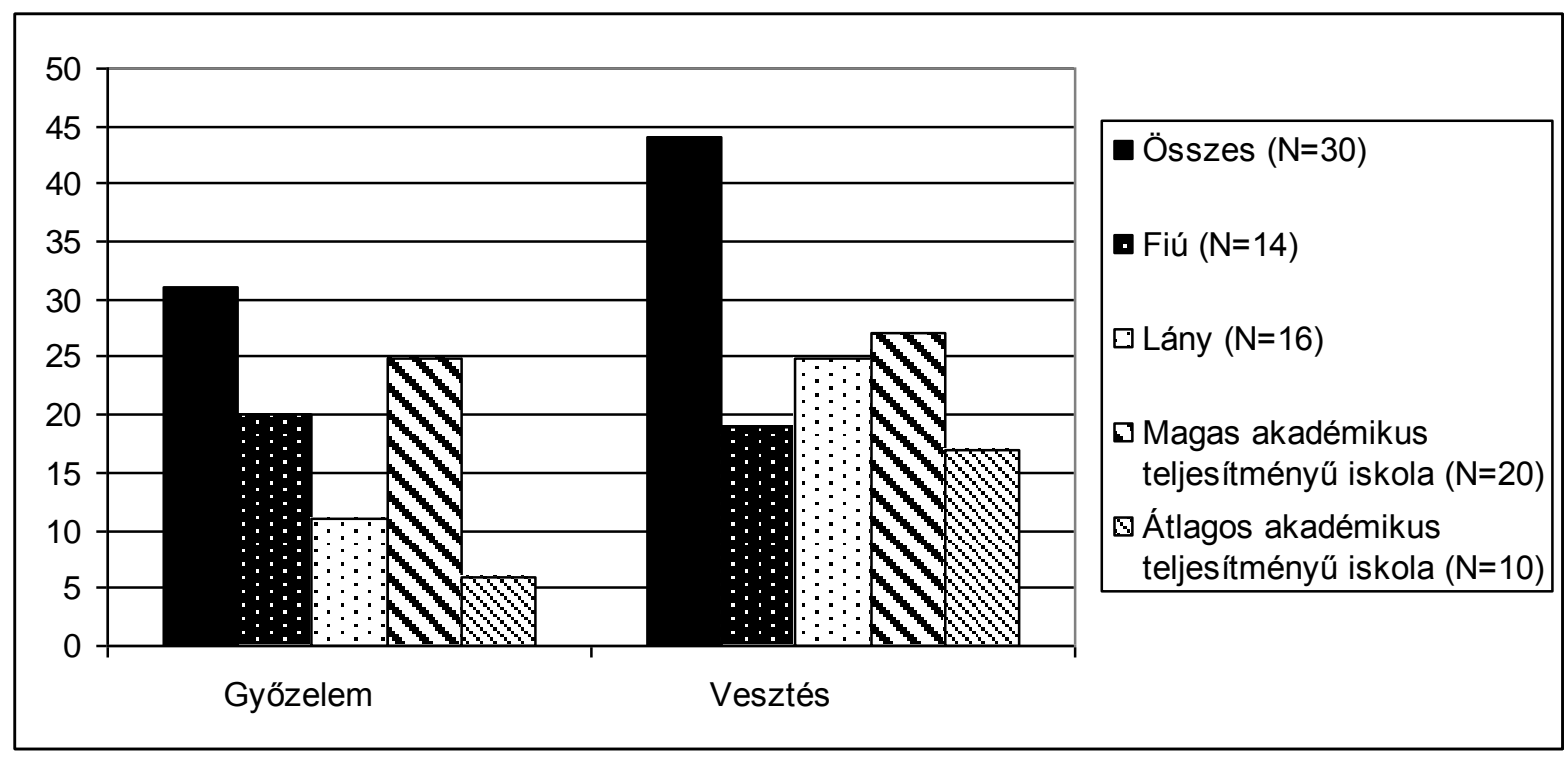

2. ábra A győzelemmel és a vesztéssel kapcsolatban megjelenített konfliktusok intenzitásának összehasonlítása a Konfliktus (CT) skála alapján

A konfliktusok megjelenítése a vesztéssel kapcsolatos rajzokra összességében jellemzőbb, mint a győzelemmel kapcsolatos rajzokra. A különbség tendencia-szinten szignifikáns $(\mathrm{t}(29)=-1,783 ; \mathrm{p}<0,1)$.

\section{Nemi különbségek}

A fiúk győzelemmel és vesztéssel kapcsolatos rajzai nem különböznek egymástól a rajtuk megjelenített konfliktusok mértékében. A lányok a vesztéssel kapcsolatban szignifikánsan több konfliktust jelenítenek meg, mint a győzelemmel kapcsolatban $(t(15)=-2,671 ; p<0,05)$.

\section{Iskolatípusok szerinti különbség}

Az átlagos akadémiai teljesítményű iskolába járó gyerekek a vesztéssel kapcsolatban súlyosabb konfliktusokat jelenítenek meg rajzaikon, mint a győzelemmel kapcsolatban $(\mathrm{t}(9)=-$ 
$3,161 ; p<0,05)$, vagyis inkább megkülönböztetik a győzelemmel és a vesztéssel kapcsolatos perspektívát, mint a magasabb tanulmányi teljesítményü iskolába járó gyerekek, akik esetében nincs szignifikáns különbség. Iskolatípusok mentén szintén nem mutatkozott szignifikáns különbség.

\section{Összegzés}

Jelen tanulmány célja 8-9 éves korú kisiskolás gyermekek győzelemmel és vereséggel kapcsolatos fogalmainak rajzvizsgálat során feltárt sajátosságainak bemutatása volt. A rajzok elemzéséhez a PAIR (Bombi és mtsai, 2007) technikát alkalmaztuk, amely olyan komplex elemzési-rendszert kínált (Sándor, Fülöp, Sebestyén, megjelenés alatt), amellyel lehetőség nyílt megvizsgálni egyrészt győztes és vesztes kapcsolatának ábrázolását szituációtól függetlenül, valamint a győzelemnek és vesztésnek a hatását győztes és vesztes viszonyának alakulásában, azaz, hogy változik-e győztes és vesztes kapcsolata attól függően, hogy a győzelem vagy a vesztés kerül a fókuszba.

A gyermekek szituációtól függetlenül világosan elkülönítették a győztes és vesztes figuráját rajzaikban. A versengés szereplöit hierarchikus viszonyban helyezték el, a győztest mind a győzelem, mind a vesztés rajzokkal kapcsolatban értékesebbnek, dominánsabb pozícióban ábrázolták, mint a vesztest. A győztes dominanciáját fejezte ki, hogy nagyobb látószöggel jelenítették meg. Azzal, hogy a győztes látóterében benne van a vesztes, lehetősége nyílik az egész szituáció, valamint a vesztes kontrollálására is. A vesztest általában ,alávetettebb” helyzetben ábrázolják, tipikusan nem lát rá a győztesre, nincs lehetősége annak kontrollálására. A gyermekek sok esetben dobogón jelenítik meg a győztest és a vesztest (Fülöp és Sándor, 2008). Ha figyelembe vesszük, hogy az emeletes dobogó építménye a díjkiosztó ünnepségek általános strukturális eleme, akkor látható, hogy a győzelem és vesztés kulturálisan úgy van megkonstruálva, hogy a győztes rálásson a vesztesre, ezáltal dominánsabb pozícióba kerüljön, míg a vesztesnek, azzal, hogy a dobogó alsó fokán helyezkedik el, nincs megadva ez a fajta kontroll. A győzteseket továbbá a szakirodalomban leírtakhoz hasonlóan (pl. Baker-Ward és mtsai, 2005; Sándor, 2010) perspektívától függetlenül jellemzően elégedettnek ábrázolták a gyermekek, míg a vesztesek elégedetlenebbnek voltak megjelenítve.

Bár győztes és vesztes viszonyának ábrázolásában találhatók általános, szituációtól független jellemzők (pl. a győztes értékesebb, dominánsabb, elégedettebb), győztes és vesztes eltérö perspektívája szituációk menti eltérésekhez is vezetetett a két figura kapcsolatának megjelenítésében. Ahogy Baker-Wardék (2005) vizsgálatában a győztes és vesztes csapat tagjai eltérö információfeldolgozást választottak és ugyanannak a versengési folyamatnak eltérő részeire fókuszáltak, jelen vizsgálat szintén különbséget mutatott attól függően, hogy a gyermekek a győztes vagy a vesztes perspektíváját vették föl. A győzelemmel kapcsolatos rajzokon a győztes és vesztes figurákat összetartozóbbnak ábrázolták a gyermekek, az egymásra utaltság kifejezése jelentősebb volt, mint a vesztés helyzetében. Győzelem esetén fizikailag közelebb helyezték egymáshoz a győztest és a vesztest, valamint gyakrabban ábrázolták őket közvetlen vagy közvetett testi kontaktusban, míg vesztés során a vesztes izolálása és fizikailag messzebb helyezése volt jellemzőbb. Az egész vizsgálati anyagot figyelembe vevő, hagyományos rajzelemzési technikával kapott eredmények szintén arról számoltak be, hogy a győzelem sokkal inkább egy szociális összetartozást igénylő esemény, a győztes rajzokon gyakrabban szerepeltetik a gyermekek a közönséget, illetve a versenytársakat (Fülöp és Sándor, 2008). 
Az eredmények arra is rámutatnak, hogy bár győzelem esetén fizikailag közelebb helyezik el a győztes és vesztes figurákat a gyermekek, a figurák megkülönböztetése is kifejezettebb lesz. A győzelmet helyezve a fókuszba nagyobb értékkülönbség jelentkezik győztes és vesztes figurái között, mint a vesztésre fókuszálva. Legértékesebbként a győzelem szempontjából megjelenített győztes figurát ábrázolják.

A győztes és a vesztes között megjelenő kisebb értékkülönbség a vesztés rajzokon arra utal, hogy vesztes perspektívából, amikor valószínüsíthetően a vesztessel azonosul a rajzoló, a különbség csökkentésére lesz motivált, azaz a vesztés érzelmi terhét a különbség tompításával kívánja csillapítani. A vesztes perspektívájából bekövetkező különbségcsökkentés tehát egy olyan kompenzációs mechanizmust jelezhet, amely segíti a vesztest a negatív kimenetel, a vesztés emocionális terhével való megküzdésben. Míg a győzelemre fókuszálva, amikor az azonosulás valószínűsíthetően a győztessel történik, szabadon kifejezhetőek lesznek a győztes pozitív érzelmei, nem lép fel motiváció a különbség csökkentésére.

Győzelem és vesztés érzelmi szempontból is világosan megkülönböztethető a gyermekek reprezentációjában. A győzelem a 8-9 éves gyerekek számára jellemzően örömteli folyamat és döntően pozitív érzelmek kapcsolódnak hozzá. A győzelemre fókuszálva van lehetőség leginkább a pozitív érzelmek kifejezésére, a győztes figurájával való azonosulás és perspektívájának felvétele még a vesztes fél érzelemkifejezését is pozitív irányban befolyásolja. A győzelem tehát inkább takar homogén jelenséget a gyermekek számára, többnyire a pozitív érzelmek tiszta megjelenítésével. Ugyanakkor mivel a győzelem rajzokon megjelenített vesztes kevésbé tünik elégedetlennek, mint a vesztés fókuszú rajzokon, feltételezhető, hogy a győztes szerepébe való belehelyezkedés (ami a győzelem rajzok hátterében állhat) kevéssé teszi őket fogékonnyá a vesztes fél érzelmi állapotának pontos felmérésére. Fülöp (1992) tehetséges gyermekekkel végzett vizsgálatában szintén azt találta, hogy a győzelem felett érzett örömbe való belefeledkezés képes csökkenteni a riválissal szemben érzett empátiát. A vesztés másrészről a győzelemmel szemben egy sokkal konfliktus telibbnek ábrázolt, érzelmileg ambivalensebb szituáció, amikor a vesztes kerül a fókuszba, negatív érzelmei, elégedetlensége szabadabban fejeződnek ki. A győzelemmel és vesztéssel kapcsolatos asszociációs vizsgálatok (Sándor, Orosz és Fülöp, 2010) szintén e fogalmak (győzelem és vesztés) erős érzelmi színezettségét mutatják: a két fogalom központi magját az eseménnyel járó érzelmek, győzelem esetén az öröm, vesztés esetén a szomorúság alkotják. Fülöp és Berkics vizsgálatában (2007) gimnazisták győzelemre adott reakciómódjai között szintén kiemelkedett az aktiváló öröm kifejezése („öröm és azt követő aktiváció”), vesztés esetén pedig a negatív kimenetel felett érzett szomorúság és harag („szomorúság és frusztráció").

Az eredmények jelentős nemi különbségekre is rámutatnak. A lányok kifejezettebben különböztetik meg egymástól a győztes és vesztes perspektíváját, érzékenyebben reagálnak a versengés különböző eredményire. A győzelemmel kapcsolatban a győztest egyértelmüen kiemelik, míg a vesztéssel kapcsolatban a vesztest helyezik az adott történet „középpontjába”. A lányok konfliktus telibbnek ábrázolják a vesztést, melynek erőteljesebb érzelmi terhéről tanúskodik továbbá, hogy kifejezettebben törekszenek vesztés esetén a győztes és vesztes figurák közötti értékkülönbség csökkentésére; a vesztéssel kapcsolatban megjelenített veszteshez értékesebbnek ábrázolják, mint a győzelemmel kapcsolatban megjelenített veszteseket. Fülöp és munkatársai más vizsgálatai (Sándor és Fülöp, 2008, Fülöp, 2013) szintén arról számolnak be, hogy a lányok számára érzelmileg megterhelőbb a vesztés, gyakrabban fejezik ki a vesztés negatív érzelmeit, mint a fiúk. A stressz nemi különbségeinek irodalma szintén a nők sérülékenységét írja le; a nők érzékenyebben reagálnak a negatív életeseményekre, fokozottabb stresszválaszokat adnak, és szubjektíve nehezebben élik meg őket, mint a férfiak (Dalgard és mtsai, 2006; You és Conner, 2009; Szabó és mtsai, 2010). 
Jelen vizsgálatban a fiúk esetében a nyerö-vesztő helyzettel kapcsolatos szerepek (győztesvesztes) felülírják az egyes fogalmakkal (győzelem-vereség) kapcsolatban megjeleníthető nézőpontbeli különbségeket. Rájuk az jellemző, hogy mind a győzelemmel, mind a vesztéssel kapcsolatban ugyanazt a társas mintázatot jelenítik meg, csupán az adott mintázat intenzitása különbözik a győzelemmel és a vesztéssel kapcsolatos helyzetek mentén.

Érdekes eredmény továbbá, hogy míg a győztes és vesztes figurák értékkülönbségét a lányok jellemzően olyan kevésbé explicit, árnyaltabb eszközökkel fejezik ki, mint a győztes felnagyítása, és dominánsabb pozícióba helyezése, addig a fiúk inkább a direkt, kézzelfogható győzelemre utaló attribútumokkal (korona, kupa, érem) való felruházást, valamint a győztes részletesebb kidolgozását választják a kiemelés eszközéül. Az eredmények összefüggésbe hozhatóak a lányok jellemzően kevésbé nyílt, rejtettebb, és a fiúk nyíltabb, direkt versengésével (Pepitone, 1980; Tracy, 1991; Fülöp, 2005). Továbbá az eredmények alapján úgy tünik, hogy már kisiskolás gyermekek rajzain felfedezhetőek a versengés területeiben megmutatkozó nemi különbségek vizuális jelei, miszerint a férfiak a versengés materiális javakkal járó változatát preferálják, míg a nők a társas elismerést és interperszonális kapcsolatokat helyezik előtérbe (Peterson, 2004). Agytérképező vizsgálatok eredményei szintén azt mutatják, hogy a férfiak pénzjutalom kilátásba helyezésére kiterjedtebb mezolimbikus (jutalomhoz kapcsolódó agyi területek) agyaktivációt mutattak, mint társas elismerés esetén (Spreckelmeyer és mtsai, 2009).

Jelen vizsgálat iskolatípus menti különbségeket is feltárt. A lányok eredményéhez hasonlóan az átlagos akadémiai teljesítményü iskolába járó gyermekek jellemzőbben megkülönböztették a két helyzetet (győzelem és vesztés), mint a magasabb akadémiai teljesítményü iskola tanulói. Erősebben vették figyelembe a vesztes perspektíváját vesztés esetén, így a vesztéssel kapcsolatban megjelenített vesztest értékesebbnek ábrázolták, valamint elégedetlenebbnek az eredménnyel. Ezzel összhangban az átlagos akadémiai teljesítményü iskolába járó gyermekek vesztés reprezentációja konfliktustelibb, mint a magasabb akadémiai teljesítményü iskolába járó társaik esetében. Mivel a magasabb tanulmányi követelményeket támasztó iskolákban a gyermekek gyakrabban vesznek részt versenyhelyzetben, inkább lehetőségük van a verseny kimeneteleinek gyakoribb, mindkét oldalról (győzelem és vesztés) történő megtapasztalására és adaptív megküzdési mechanizmusok kialakítására. Sándor (2010) mélyinterjús vizsgálatából az derül ki, hogy a magas akadémiai teljesítményü iskolába járó, magukat sikeresnek ítélő gyermekek konstruktívabb attitüddel álltak a vesztéshez, képesek voltak annak pozitív aspektusát is észlelni. Ebben pedig a tanári üzeneteknek meghatározó szerepe lehet, Pressing és Fülöp (2011) vizsgálatának eredményei szerint a magas tanulmányi színvonalú iskolák tanárai fordítják a legnagyobb hangsúlyt a győzelem és vesztés megfelelő kezelésére.

Összegezve megállapítható, hogy a vizsgálatban szereplő 8-9 éves gyermekek győzelemmel és vesztéssel kapcsolatos fogalmai eltérően reprezentálódnak, továbbá nemi és iskolatípus menti különbséget is mutatnak. A különbség kifejezésre juttatása a PAIR eljárásban szereplő elemzési-kategóriák többségében feltárható volt, amely jelzi a koncepciók már kisiskoláskorban megjelenő komplex kezelését, több dimenziós felfogását. 


\section{Irodalomjegyzék}

Ahlgren, A., Johnson, D.W. (1979). Sex Differences in Cooperative and Competitive Attitudes From the 2nd Through the 12th Grades. Developmental Psychology, 15 (1), 45-49.

ARCHER, J. (2006). Cross-cultural differences in physical aggression between partners: A social-role analysis. Personality and Social Psychology Review, 10, 13-153.

BAKER-WARD, L. E., EAtOn, K. L., BANKS, J. B. (2005). Young Soccer Players' Reports of a Tournament Win or Loss: Different Emotions, Different Narratives. Journal of Cognition and Development, 6 (4), 507-527.

Bartsch, K., Wellman, H. M. (1995). Children talk about the mind. Cambrigde, MA: Harvard University Press

BENENSON, J. F. (1990). Gender differences in social networks. Journal of Early Adolescence, 10, $472-495$.

Benenson, J. F., Apostoleris, N. H., Parnass, J. (1998). The organization of children's same-sex peer relationships. In: W. M. Bukowski, A. H. Cillessen (Eds.), Sociometry then and now: Building on six decades of measuring children's experiences with the peer group. San Francisco: Jossey-Bass. 5-24.

Benenson, J. F., Nicholson, C., Waite, R., Roy, R., Simpson, A. (2001). The influence of group size on children's competitive behavior. Child Development, 72, 921-928.

Bombi, A. S., Pinto, G., CANNONI, E. (2007). Pictorial assessment of interpersonal relationships (PAIR): An analytic system for understanding children's drawings. Firenze: Firenze University Press

BRIM, G. (1988). Losing and winning. Psyhology Today, Sept., 48-52.

Dalgard, O. S., Dowrick, C., Lehtinen, V., VAZQuez-BArquero, J. L., CASey, P., Wilkinson, G., Ayuso-Mateos, J. L., Page, H., Dunn, G. (2006). Negative life events, social support and gender difference in depression: a multinational community survey with data from the ODIN study. Social Psychiatry and Psychiatric Epidemiology, 41, 444-451.

Flavell, J. (1999). Cognitive development: Children's knowledge about the mind. Annual Review of Psychology, 50, 21-45.

FÜLÖP, M. (1992). A tehetséges gyerekek versengő magatartásáról, Új Pedagógiai Szemle, 5, 3-13.

FÜLÖP, M. (2001). A versengés szerepe. Új Pedagógiai Szemle, 11. 3-17.

FÜlÖP, M. (2005). The role of gender in competition viewed by Canadian, Hungarian and Japanese young adults. Elöadás a VII Regional Congress of the International Association of Cross Cultural Psychology. July 11-15, San Sebastian, Spain.p.237

FÜLÖP, M., BERKICS, M. (2003). Socializations for coping with competition, winning and losing in twosocieties: Hungary and the UK. In: A. Ross (eds.) A Europe of Many Cultures. London: CICE Publication. 263-273.

FÜlÖP, M., BERKICS, M. (2007). A győzelemmel és a vesztessel való megküzdés mintázatai serdülőkorban. Pszichológia, 27 (3), 194-220.

Fülöp, M., Ross, A., Pergar Kuscer, M., Razdevsek Pucko, C. (2007). Competition and cooperation in schools. An English, Hungarian and Slovenian comparison. In: F. Salili., R. Hoosain (eds.), Research in Multicultural Education and International Perspective, Vol 6: Culture, Motivation and Learning: A Multicultural Perspective. Greenwich, CT: Information Age Publishing. 235-284.

FÜlÖP, M., SÁNDOR, M. (2008). A versengés, a győzelem és a vesztés fogalma kisiskolások körében. Pszichológia. 28(2), 195-220 
GREEN, S. (2003). The psychological development of girls and woman - Rethinking change in time. London: Routledge

HALÁsz, G., LANNERT, J. (szerk.) (2003). Jelentés a magyar közoktatásról 2003. Országos Közoktatási Intézet, Budapest.

HARTER, S. (1999). The Construction of the Self. New York: Guilford

HORNER, M.S. (1972). Toward an Undesrtanding of Achievement Related Conflicts in Women, Journal of Social Issues, 28, 157-176.

HugheS, M., DunN, J. (1998). Understanding mind and emotion - Longitudinal associations with mental-state talk between young friends. Developmental Psychology, 34(5), 1026-1037.

KASIK, L. (2010). A Szociálisérdek-érvényesitö, az érzelmi és a szociálisprobléma-megoldó képességek vizsgálata 4-18 évesek körében, Doktori disszertáció. Szegedi Tudományegyetem

Knight, G. P., CHAO, C. (1989). Gender differences in the cooperative, competitive, and individualistic Social Values of Children. In: Motivation and Emotion, 13 (2), $125-$ 141.

LEVER, J. (1976). Sex differences in games children play. Social Problems, 23, 478-487.

MASTERS, J. C. (1968). Effects of social comparison upon subsequent self-reinforcement behavior in children. Journal of Personality and Social Psychology, 10, 391-401.

McClintock, C. G., Moskowitz, J. M. (1976). Children's preferences for individualistic, cooperative, and competitive outcomes. Journal of Personality and Social Psychology, 34, 543-555.

OECD (2001): Knowledge and Skills for Life. First results from the OECD programme for International Student Assessment (PISA) 2000. Paris: OECD

PEKRUN, R. (1992). The impact of emotions on learning and achievement: towards a theory of cognitive/motivational mediators. Applied Psychology, An International Review, 41, 359-376.

PePitone, E. (1980). Children in Cooperation and Competition. Toronto, Canada: Lexington Books.

Peterson, M. (2004). What Men and Women Value at Work: Implications for Workplace Health. Gender Medicine, 1 (2). 106-124.

Pons, F., LAwson, J., HARris, P. L., \& DE Rosnay, M. (2003). Individual differences in children's emotion understanding: Effects of age and language. Scandinavian Journal of Psychology, 44, 347-353.

PRESSING, ZS., FÜLÖP, M. (2011). Általános iskolai tanítók versengéssel és együttmüködéssel kapcsolatos nézeteinek kvalitatív vizsgálata. Hagyomány és megújulás . A Magyar Pszichológiai Társaság Jubileumi XX. Országos Nagygyülése (kivonatkötet). Május 25-27, Budapest. p. 124.

Price, J. (2000). Subordination, self-esteem and depression. In: Sloman, L., Gilbert, P. (eds.). Subordination and Defeat. Mawah, New Jersey: Lawrence Erlbaum Associaties, 165-177.

Roy, R., BENENSON, J. F. (2002). Sex and contextual effects on children's use of interference competition. Developmental Psychology, 38, 306-312.

Ruble, D. N., Feldman, N. S., Boggiano, A. K. (1976). Social Comparison Between Young Children in Achievement Situation. Developmental Psychology, 12, 192-197.

SAARNI, C. (1999). The development of emotional competence. New York: Guilford Press. 
SÁNDOR, M., Orosz, G., FÜLÖP, M. (2010). A versengés, a győzelem és a vesztés szociális reprezentációja 8-9 éves kisiskolások körében, Pszichológia, 30 (3), 175-205.

SÁNDOR, M., FÜlÖP, M., SEBESTYÉN, N. (megjelenés alatt) A PAIR (Pictorial Assessment of Interpersonal Relationship) rajzvizsgálati módszer bemutatása, Magyar Pszichológiai Szemle

SÁNDOR, M. (2010). A versengés, a győzelem és a vesztés fogalma kisiskolás korban. Doktori disszertáció. ELTE

SCHNEIDER, B., BENESON, J., FÜlÖP, M., BERKICS, M., SÁNDOR, M. (2011). Cooperation and Competition. In: SMITH, P.K., HART, C.H. (eds.) The Wiley-Blackwell Handbook of Childhood Social Development. London: Blackwell Publishing Ltd., 472-490.

SElman, R. L. (1980). The growth of interpersonal understanding: Developmental and clinical analyses. New York: Academic Press.

Sloman, L., Gilbert, P. (eds.) (2000). Subordination and Defeat. Mawah, New Jersey: Lawrence Erlbaum Associaties

Sloman, L. (2000). How the Involuntary Defeat Strategy Relates to Depression. In: SLOMAN, L., Gilbert, P. (eds.). Subordination and Defeat. Mawah, New Jersey: Lawrence Erlbaum Associaties, 199-214.

Spreckelmeyer, K. N., Krach, S., Kohls, G., Rademacher, L., Irmak, A., Konrad, K., KIRCHER, T., GRUNDER, G. (2009). Anticipation of monetary and social reward differently activates mesolimbic brain structures in men and women. Social Cognitive and Affective Neuroscience, 4(2), 158-65.

SzabÓ, G., SzÁntó, Zs., Balog, P., KopP, M. (2010). Az életesemények, a stressz és a megküzdés nemi különbségei. Mentálhigiéné és pszichoszomatika, 11 (4), 349-369.

TóTH, E., CsAPÓ, B., SzÉKely, L. (2010) Az iskolák és osztályok közötti különbségek alakulása a magyar iskolarendszerben, Közgazdasági Szemle, 57, 798-814.

TÓTH, E., KASIK, L. (2010). Szülői vélekedések a szociálisérdek-érvényesítő viselkedéssel kapcsolatos anyagi, szellemi és kapcsolati erőforrásokról. Új Pedagógiai Szemle, 60 (1-2), 93-119.

Tracy, L. (1991). The Secret Between Us. Competition among Women. Boston: Little, Brown and Company

You, S., CONNER, K. R. (2009). Stressful life events and depressive symptoms: influences of gender, event severity, and depression history. Journal of Nervous and Mental Disease, $197,829-833$. 